\title{
The expression level of genes encoding LysM-RLKs of potato after stimulation with chitin
}

\author{
ZAHRA MOHAMMADI, FARHAD NAZARIAN-FIROUZABADI ${ }^{\bowtie}$, \\ ZIBA NAZARI
}

Department of Agronomy and Plant Breeding, Faculty of Agriculture, Lorestan University, Khorramabad, Iran

Received: 08.12.2020

Accepted: 12.22 .2020

Mohammadi Z, Nazarian-Firouzabadi F, Nazari Z (2020). The expression level of genes encoding LysM-RLKs of potato after stimulation with chitin. Plant Pathology Science 9(2):37-50. DOI: 10.2982/PPS.9.2.37.

\section{Abstract}

Introduction: Lysine motif receptor-like kinases (LysM-RLKs) play an important role in the defense reaction of plants to diseases and environmental stresses. This study was conducted to investigate the effect of chitin as a stimulus for the expression of genes that encode LysM-RLKs. Materials and Methods: The expression levels of three genes PGSC0003DMP400010799, PGSC0003DMP400010800 and PGSC0003DMP400061331, which encoded LysM-RLKs due to chitin treatment (150 $\mu \mathrm{g} / \mathrm{ml}$ ) in young seven-week potato leaves of Jely cultivar, were examined in treated and control leaves. Results: Analysis of the gene expression data showed that the expression of all three genes increased significantly due to the use of chitin compared to the control. Conclusion: Increasing the expression of genes encoding LysM-RLKs using chitin can be effective to induce systemic resistance to plant diseases and environmental stresses.

Key words: Disease, Gene cascade, Gene Expression, Potato, Receptor Kinase

$\bowtie$ Corresponding author: nazarian.f@lu.ac.ir 


$$
\begin{aligned}
& \text { مقاله يروهشى } \\
& \text { سيبزمينى هـ از القا با محرى كيتين } \\
& \text { زهرا محمدى، فرهاد نظريان فيروزآبادى هـ، زيبا نظرى } \\
& \text { گروه مهندسى توليد و زنتيك گياهى، دانشكده كشاورزى، دانشگاه لرستان } \\
& \text { دريافت: r/ }
\end{aligned}
$$

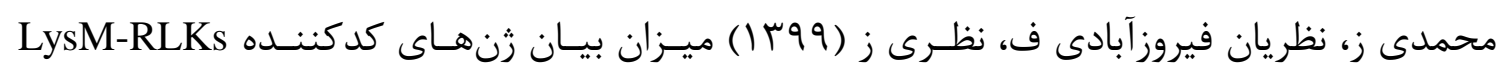

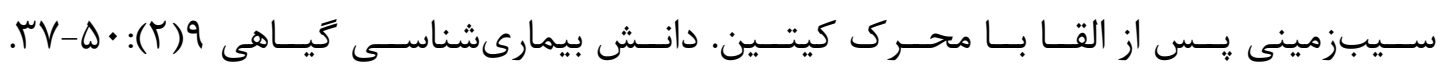

DOI:10.2982/PPS.9.2.37.

مقدمه: گيرندههاى شبهكينازى داراى موتيف ليزين (LysM-RLKs) سهمم مهمى در مسير پاسخ دفاعى گياهان به بيمارىها و تنشهاى محيطى دارند. اين يزوهش براى بررسى تاثير كيتين به عنوان محرك بيان زنهاى كدكننده LysM-RLKs انجام شد. مواد و روشها: ميزان بيان سه زن PGSC0003DMP400061331 و PGSC0003DMP400010800،PGSC0003DMP400010799 كدكننده LysM-RLKs در اثر تيمار با كيتين (Mg/ml • Dl) در برگهاى جوان سيبزمينى هفت هفتهاى رقم Jely در برگهاى تيمار شده و شاهد بررسى گرديد. يافتهها: تجزيه و تحليل دادههاى بيان زنها نشان داد كه بيان هر سه زن نسبت به شاهد به صورت معنى دارى در اثر استفاده از كيتين افزايش مىيابد. نتيجهگيرى: افزايش بيان زنهاى كدكننده LysM-RLKs با استفاده از كيتين مى تواند در القاى مقاومت سيستميك به بيمارىهاى گياهى و تنشهاى محيطى مؤثر باشد. وازگًان كليدى: آبشار زنى، بيان زن، بيمارى، سيبزمينى، گيرندهاى كينازى

\section{Introduction}

سيبزمينى (Solanum tuberosum.L) از مهمترين محصولات غذايى جهان با توليد • بr ميليون تن در سال است (Faostat 2016). ايران با توليد بيش از rا ميليون تن در سال، سيزدهمين توليد كننده مهرم اين محصول در جهان است (Abedini et al. 2020). بيمارىهاى مهمى مانند، يوسيدگى ريشه سيبزمينى (Rhizoctonia solani. Kühn)، يوسيدگى خشك (Fusarium spp)، سوختخى (R)

هويستده مسئول: nazarian.f@lu.ac.ir 
زودهنگام (Alternaria solani. Sorauer)، سوختكى ديرهنگام سيبزمينى Phytophthora) Vericllium dahliae. Kleb and Vericllium albo-) يزمردگى ورتيسيليومى infestans. Mont) و يزٔمردگى باكتريايى سيبزمينى (atrum Reinke نرم باكتريايى (Pectobacterium carotovorum Jones) بيمارى جرب معمولى ( Sterptomyces) و ولولهاى شدن برگ سيبزمينى (scabies Gussow ديكرى از بيمارگرهاى مهرم سيبزمينى را در طول مدت رشد و نمو آن تحت تأثير قرار مىدهند و خسارت زيادى به محصول و كيفيت آن وارد مى كنند (Moslemkhani and Mozafari 2016). كياهان در مواجهه با عوامل بيمارىزا ٍاسخهاى متفاوتى از خود نشان مىدهند، مقاومت سيستميك اكتسابى يكى از اين ياسخها است. اين نوع پاسخ مىتوانـد به وسيله زنهاى غيربيمارىزاى بيماركرها و يا عوامل غيرزنده فيزيكى و شيميايى موسوم به محركها القا شود (Durrant and Dong 2004). سلولهاى گياهى قادر به درك نشانههاى ميكروبى تحت عنوان الكوهاى مولكولى همراه بيماركر مى باشند. الخوهاى مولكولى بيمارگرى به وسيله گيرندهاى تشخيص گياه موسوم به گيرندههاى شناساگر الكو قابل تشخيص مىباشند (Zipfel 2009). تشخيص سريع الكوهاى مولكولى مرتبط با ميكروبها توسط گيرندهایى شناساگر الگوها اولين مرحله در شروع ايمنى ذاتى در گياه است كه به آن ايمنى Jones and Chisholm et al. 2006) ناشى از الكوهاى مولكولى مرتبط با ميكروب اطلاق مىشود (Dangl 2006, تشخيص الخوىهاى مولكولى بيمارگرى به وسيله گيرندههاى تشخيص الكوى كياه باعث حفاظت گياه در مقابل بيمارگرهاى غيرميزبان و همجنين موجب محدود كردن بيمارىهايى مى شود كه به وسيله بيماركرها ايجاد مىشود (Bittel and Robatzek 2007). بهطور كلى، در زمان حمله يكى قارج بيمارگر، آبشارى از زنهاى درگير در سيستمهاى دفاعى در زياه ميزبان فعال مىشوند

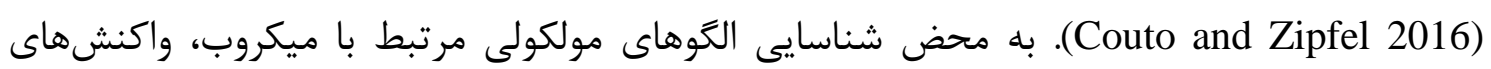
دفاعى خاص و موثرى مانند افزايش نشر يونى در طول غشاى يلاسمايى، بيوسنتز اتيلن و تحريك آبشار يروتيين كينازها توسط ميتوزن رخ مىدهد (Asai et al. 2002). توليد فرمهاى فعال اكسيزن، تجمع كالوز و تحريك نسخdبردارى زنهاى كدكننده يروتئينهايى مانند: ديفنسين (يروتيينهاى ضدميكروبى)، آنزيمهاى ليزكننده و آنزيمهاى سنتزكننده فيتوالكسينها (متابوليتهاى ثانويأ

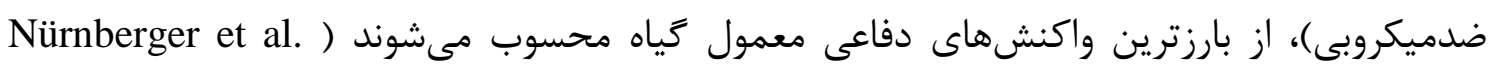
.(2004

خانواده يروتيينى كيرندههاى كينازى/شبهكينازى از نظر طول، توالى، تعداد دومين و نحوه يروتيين فعاليت دومينهاى كاتاليتيكى متنوع هستند و بسيارى از آنها نقش مهمى در رشد و تكامل كياهان 
دارند كه از جمله زنهاى درگير در پاسخ ايمنى گياهان به تنشها هستند. گياه مدل آرابيدويسيس تاليا، داراى بيش از • إع عضو از گيرندههاى كينازى/شبه كينازى است و تنها عملكرد تعداد اندكى از آنها مشخص شده است كيرندههاى شبه كينازى داراى موتيف ليزين از جمله اولين كيرندههاى مهمى بودند كه از طريق بررسى زنومهاى آرابيدويسيس و بعداً برنج شناسايى شدند ( Shiu and Bleecker 2001). مدتى بعد، نقش اين :روتيينها در خياهان Medicago truncatula Lotus japonicus در جريان برقرارى ارتباط همزيستى بين باكترىهاى ريزوبيوم تثبيت كننده ازت مشخص گرديد (Radutoin et al. 2003, Limpens et al. 2003) كينازى داراى موتيف ليزين خانواده بسيار بزرگى از گيرندهاى شبهكينازى هستند كه با Shiu and Bleecker كينازها از نظر فيلوزنتيكى در يك گروه تك نيايى قرار مى گيرند IRAK/Pelle 2001). خانواده گيرندههاى شبه كينازى داراى موتيف ليزين به وضوح به دو زير گروه متمايز تقسيم مىشوند كه يروتيينهاى هر دو زيركروه حاوى يك بخش خارج سلولى مىشوند كه داراى يك تا جند موتيف ليزين هستند ( Arrighi et al. 2006, Zhang et al. 2007 ). دومين ليزين علاوه بر خياهان، Bateman and Bycroft 2000, Buist et al. ) در ساير موجودات عالى و باكترىها نيز ديده مىشود 2008), محققان در برنج يروتيينى به نام CEBiP, را شناسايى كردند كه در اتصال به كيتين آزاد, شده از ديواره بيماركرهاى قارجى نقش مهمى بازى مى كند (Kaku et al. 2006). بر خلاف اكثر كيرندهاى شبه كينازى داراى موتيف ليزين، يروتيين CEBiP فاقد يك دومين كينازى درون سيتويلاسمى است، بنابرابن رِ از اتصال به كيتين با برخى از خيرندههاى شبهكينازى داراى موتيف ليزين همسايه وارد ارتباط شده تا از طريق دومين كينازى آنها مبادرت به فعال سازى آبشار يروتيين كينازها توسط ميتوزن كند. در ادامه تحقيقات، محققان در برنج يروتيين CERK1 را شناسايى كردند كه برخلاف CEBiP، داراى دو دومين ليزين خارج سلولى است و در جريان حمله قارجهاى كيتيندار و اتصال CEBiP به كيتين، به اين كميلكس متصل شده تا در نهايت آبشار يروتيين كينازها توسط

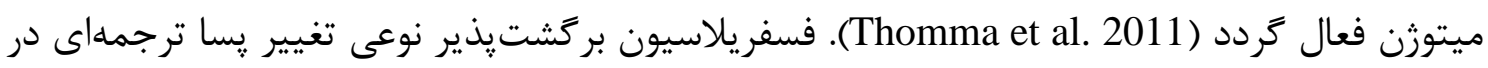
كروه زيادى از يروتيينها است كه فرآيندهاى سلولى زيادى شامل: ياسخ به تنش تا فرآيندهاى رشد و نمو را تنظيم مى كنند. آبشارهاى مي كينازى تنظيم كنندههاى حفاظت شده مهمم هستند كه در انواع فرآيندهاى سلولى مانند تمايز، تكثير، رشد، مرى سلولى شركت مىكنند. آبشارهاى يروتيين كيناز نقش مهمى در ياسخ به تنشها (زيستى، غيرزيستى) پاسخهاى هورمونى به كمك فرم فعال اكسيرن بازى مى كند (Jonak et al. 2002, Nakagami et al. 2005). هر آبشار يروتيين كيناز فعال شونده توسط ميتوزن از مجموعهاى از حداقل سه يروتيين كيناز تشكيل شده است كه به صورت متوالى عمل 
مى كنند (Takahashi et al. 2010). از آنجايى كه در جريان نفوذ قارجهاى كيتيندار بيمارگر، بيان Nazarian Firuzabadi and Kushalappa (2019) بعضى زنهاى ميزبان تحت تأثير قرار مى نشان دادند كه يس از حمله قارج Alternaria solani بيان برخى از زنهاى كدكننده كيرندهاى شبهكينازى داراى موتيف ليزين تحت تأثير قرار مى گيرد، لذا اين يزوهش، براى بررسى تأثير تيمار كيتين به عنوان يك محرك در تغيير بيان زنهاى كدكننده كيرندهاى شبه كينازى داراى موتيف ليزين (LysM-RLKs)، كه سهم مهمى در مسير ياسخ دفاعى كياهان به بيمارىها و تنشهاى محيطى دارند، در سيبزمينى انجام شد.

\section{Materials and Methods}

مواد و روشها

غدههاى سيبزمينى رقم Jely، در كلدآنهاى پِلاستيكى حاوى مخلوطى از خاى مزرعه ضدعفونى شده توسط بخار، ماسه، كود حيوانى، با نسبت س:؟: ا در عمق • إسانتىمترى محيط كلخانه كاشته شدند. در مرحله جهار بركى گياهجههاى سيبزمينى، محلول كيتين به غلظت اسيرى شد. از آب مقطر بهعنوان تيمار شاهد استفاده شد. روى بركها با نايلون يوشيده شد و بعد از

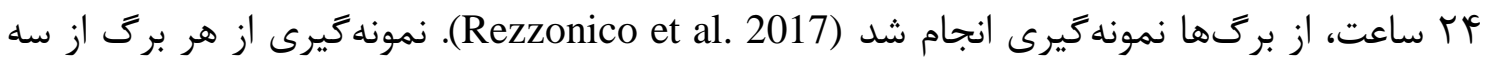
قسمت آن و از سه گياه مستقل صورت گرفت. نمونهها بلافاصله در ازت مايع منجمد شدند و براى استفاده بعدى و تا زمان جداسازى RNA در فريزر Co

جداسازى RNA و ساخت cDNA

Institute of Himalayan Bioresource Technology (IHBT) براى استخراج RNA روش استفاده شد (Ghawana et al. 2011). براى بررسى كيفيت و كميت RNA، از دستگاه اسيكتوفتومترى و الكتروفورز در زل آكارز 1\% استفاده شد. براى حذف آلودگى احتمالى DNA موجود در نمونهها، از روش تيمار با آنزيم DNase I (شركت سيناكلون) و بر اساس دستورالعمل شركت سازنده استفاده گرديد. تأييد عدم آلودگى نمونههاى RNA با DNA زنومى واكنش PCR با استفاده از

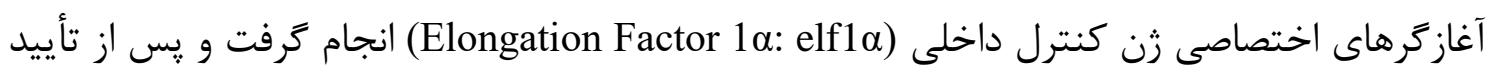
عدم آلودگى از كيت Thermo Fisher Scientific, US براى ساخت cDNA مطابق با دستورالعمل شركت سازنده استفاده شد. براى تمام نمونها، مقدار RNA يكسان و معادل . .1 نانوكرم در نظر كرفته شد. 
زنهاى

(CDS)

كدكننده

ناحيه

توالى

طراحى آغازگرها

از و PGSC0003DMP400061331 PGC003DMP40001080،PGSC0003DMP400010799

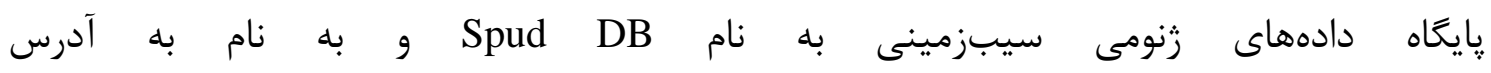
http://solanaceae.plantbiology.msu.edu AlleleID 6 (PREMIER Biosoft, Palo Alto, CA, تكثير بخشى از زنهاى مذكور از نرمافزار USA) جدول ا. فهرست آغازگرهاى طراحى شده براى تكثير گيرندهاى شبه كينازى داراى موتيف ليزين و زن كنترل داخلى

Table 1. List of designed Primers for amplification of selected LysM-RLKs and the Housekeeping gene

\begin{tabular}{|c|c|c|c|}
\hline $\begin{array}{c}\text { MRNA شماره نسخه } \\
\text { Transcript ID }\end{array}$ & $\begin{array}{c}\text { شماره نسخه يروتيينى } \\
\text { Protein ID }\end{array}$ & $\begin{array}{c}\text { نام آغازگر Namer } \\
\text { Primer Name }\end{array}$ & 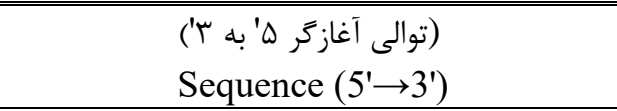 \\
\hline $\begin{array}{c}\text { PGSC0003DMT } \\
400015591\end{array}$ & $\begin{array}{c}\text { PGSC0003DMP } \\
400010799\end{array}$ & 5591-F & GTCAGGGAAGGAGGCTATCG \\
\hline & & $5591-\mathrm{R}$ & CACAGTCATCACATTCACAACAC \\
\hline $\begin{array}{c}\text { PGSC0003DMT } \\
400015592\end{array}$ & $\begin{array}{c}\text { PGSC0003DMP } \\
400010800\end{array}$ & $5592-\mathrm{F}$ & ACCTAACCGATGGCATTGTATCC \\
\hline & & $5592-\mathrm{R}$ & ССТТССТСТСТТСАСТСССТТСС \\
\hline $\begin{array}{c}\text { PGSC0003DMT } \\
400001803\end{array}$ & $\begin{array}{c}\text { PGSC0003DMP } \\
400061331\end{array}$ & $1803-\mathrm{F}$ & TCCGCCGCTGCCAACAAG \\
\hline & & $1803-\mathrm{R}$ & CATACTGATGGAGGTGGTCTTCG \\
\hline $\begin{array}{c}\text { PGSC0003DMT } \\
400059832\end{array}$ & $\begin{array}{c}\text { PGSC0003DMP } \\
400040249\end{array}$ & elfl $\alpha-F$ & ATTGGAAACGGATATGCTCCA \\
\hline & & elf1 $\alpha-R$ & TCCTTACCTGAACGCCTGTCA \\
\hline
\end{tabular}

\section{بررسى سطح بيان زنها}

و PGSC0003DMP40001080،PGSC0003DMP400010799 ميزان بيان يروتيين همولوگ يروتيين PGSC0003DMP400061331 از روش RT-PCR مورد ارزيابى قرار گرفت. براى اين كار از آغازگرهاى اختصاصى طراحى شده بر

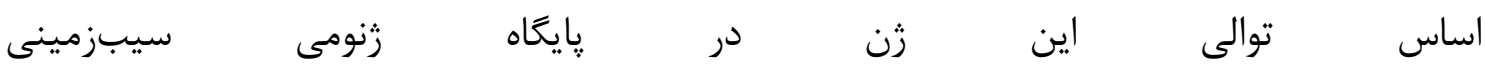
(http://solanaceae.plantbiology.msu.edu/index.shtml) سازى دادهها از تكثير زن elf-1 استفاده شد. براى مقايسه ميزان بيان زن، از روش $\Delta \Delta \mathrm{Ct}$ موسوم به روش ليواك با استفاده از فرمول (LAct)-2) استفاده شد (Livak and Schmittgen 2001). براى هريك از 
زنها دو تكرار تكنيكى و براى گياه شاهد و گياه تيمار سه تكرار در نظر گرفته شد. همجنين ميانكين نهايى دادههاى بيان زن با كمك آزمون t مورد مقايسه آمارى قرار كرفتند.

\section{Results}

يافتهها

از توالى يروتيين CERK1 كه عضوى از خانواده گيرندهاى شبه كينازى داراى موتيف ليزين در گياه آرابيدويسيس است، براى شناسايى اعضا اين خانواده در ريايگاه دادههاى زنومى سيبزمينى استفاده شد. با استفاده از توالى اين زن، در مجموع تعداد هب زن احتمالى از خانواده گيرندههاى شبه كينازى داراى موتيف ليزين شناسايى شدند كه به نظر در مسير پيام رسانى واكنش كياه سيبزمينى به تنش بيمارىهاى قارجى نقش دارند (Nazarian Firuzabadi and Kushalappa 2019). تغييرات بيان اين سه زن انتخابى نسبت به شاهد نشان داد كه ميزان بيان آنها در اثر تيمار با محلول كيتين به طور معنى دارى افزايش يافت. همان طورى كه در شكل ا ديده مىشود، نتايج مقايسه ميزان بيان اين سه زن در مقايسه با شاهد نشان داد كه ميزان بيان زن PGSC0003DMP400061331 نسبت به دو زن ديخر كمترين افزايش (Yr/9 • برابر) را نسبت به شاهد نشان داد. اين در حالى بود كه بيان زن PGSC0003DMP400010800 نسبت به شاهد / N برابر و بيان زن PGSC0003DMP400010799 نسبت به شاهد \&/\& برابر افزايش يافت.

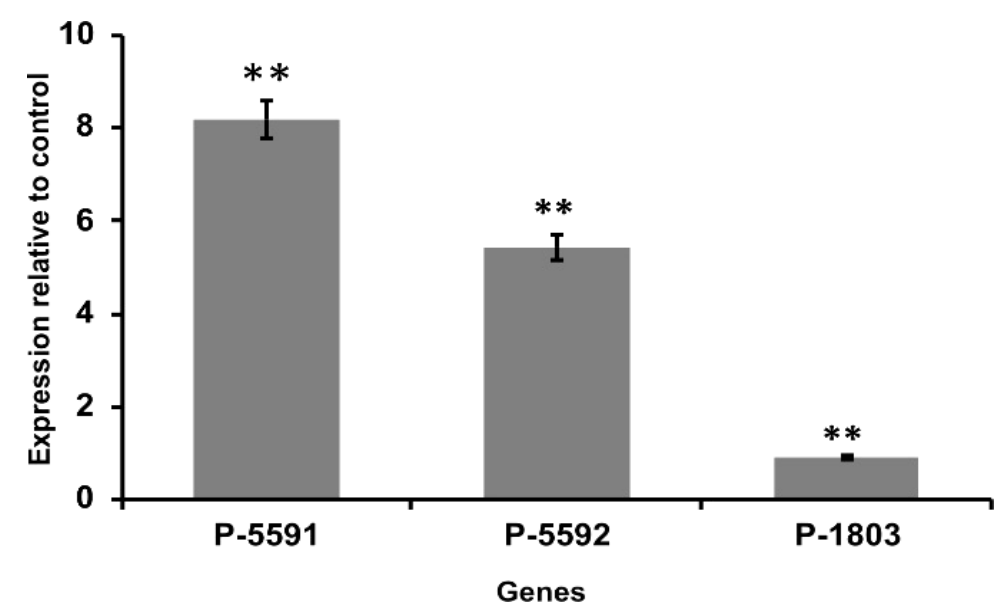

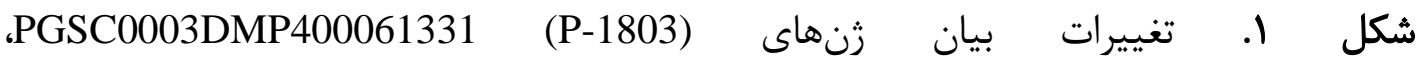
و PGSC0003DMP400010799 (P- 5591) خياهجههاى سيبزمينى يس از اعمال تيمار كيتين (

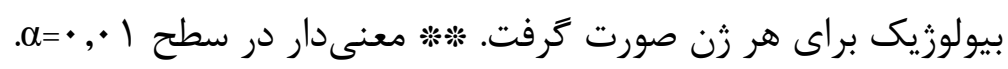

Figure 1. Expression analysis of PGSC0003DMP400061331 (P-1803), PGSC0003DMP400010799 (P-5591) and PGSC0003DMP400010800(P-5592) genes in leaves of potato seedling following chitin treatment $(150 \mu \mathrm{g} / \mathrm{ml})$. Measurements were made in three biological replicates for each gene. ${ }^{*}$ Significant at $\alpha=0.01$. 
A)

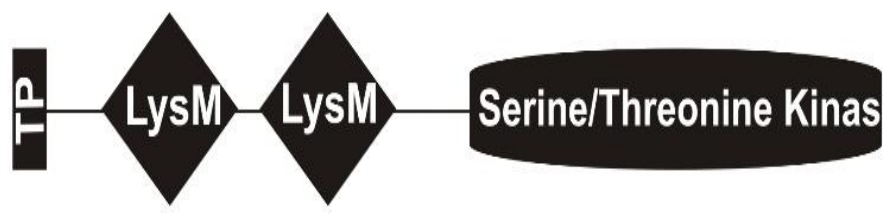

B)

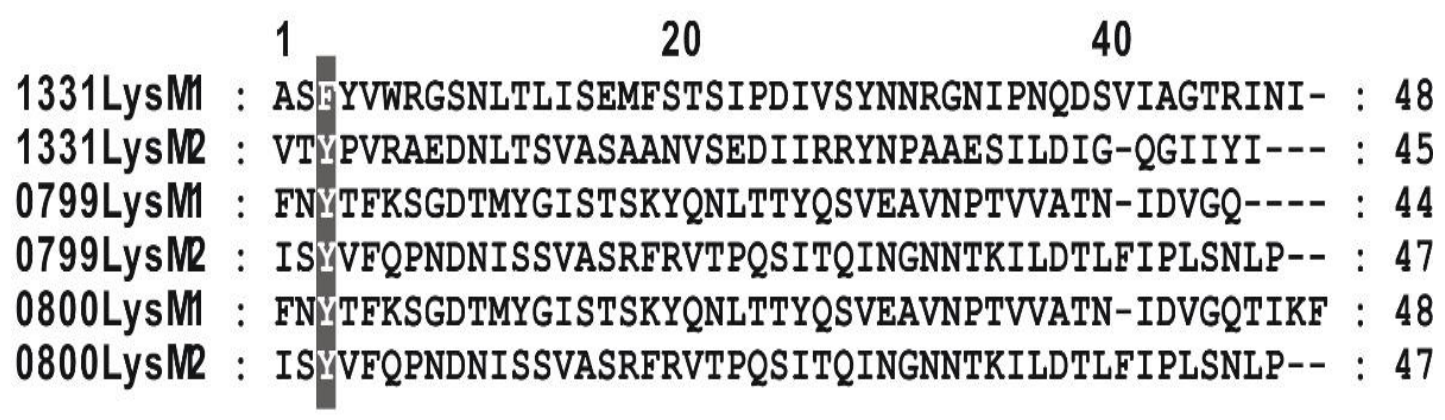

شكل r. تصوير شماتيك يك گيرنده شبهكينازى داراى موتيف ليزين: A) همرديفى קندكانه موتيف

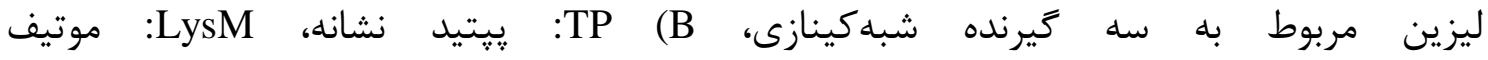

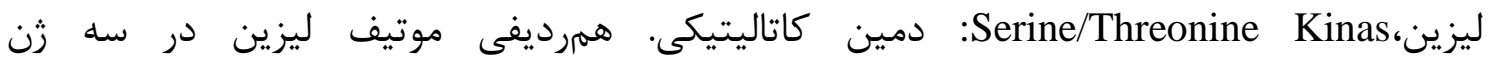
PGSC0003DMP400061331 PGSC0003DMP400010800،PGSC0003DMP400010799 با استفاده از الكوريتم Clustal W صورت كرفت.

Figure 2. Schematic representation of a LysM-RLK: A) Multiple sequence alignment of LysM three LysM-RLKs, B) TP: Signal Peptide; LysM: Lysin Motif; Serine/Threonine Kinas: Catalytic domain. Multiple Sequence Alignment of LysMs from PGSC0003DMP400010799, PGSC0003DMP400010800 and PGSC0003DMP400061331 genes was done using the Clustal W algorithm.

سه زن انتخابى داراى دومين خارج سلولى متشكل از دو تكرار موتيف ليزين هستند (شكل YA). همرديفى موتيفهاى LysM در شكل B2 ديده مىشود. همانطورى كه در شكل ديده مىشود، طول اين موتيفها، حتى دو موتيف مربوط به يك كيرنده شبه كينازى با هم متفاوت است. بين دو موتيف همان تشكيل دهنده يك كيرنده شبه كينازى مشابهت بيشترى نسبت به موتيفهاى دو بروتيين كيرنده

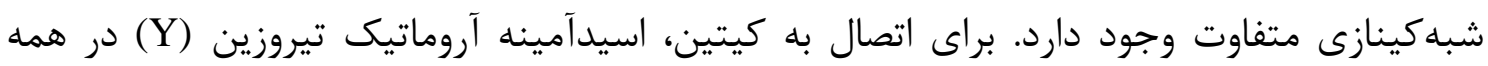
موتيفها بجز موتيف اول يروتيين PGSC0003DMP400061331 حفظ شده است. در اين موقعيت در موتيف اول يروتيين PGSC0003DMP400061331 اسيدآمينه آروماتيك فنيل آلانين (F) قرار دارد. همرديفى كلى سه بروتيين شبهكينازى داراى موتيف ليزين نيز در شكل ب نشان داده شده 


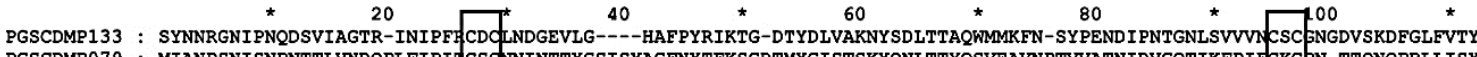
PGSCDMP079 : MIANPSNISNPNTTLVNDQPLFIPI CS CNNINTTYGSISYAGFNYTFKSGDTMYGISTSKYONLTTYOSVEAVNPTVVATNIDVGQTIKFPI CKC PN-TTQNQPRLIISY PGSCDMP080 : MIANPSNISNPNTTLVNDQPLFIPI CS GNINTTYGSISYAGFNYTFKSGDTMYGISTSKYQNLTTYQSVEAVNPTVVATNIDVGQTIKFPI FCKC PN-TTQNQPRLLISY

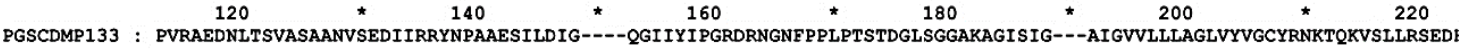
PGSCDMP079 : VFOPNDNISSVASRFRVTPOSITOINGNNTKILDTLFIPLSNL PNLTOPASSNTPPPPPAPAPVIOENDRKETVIGLAIGLGVCGLLLILILGLFYKEKTVKKEKYGDVERO PGSCDMP080 : VFOPNDNISSVASRFRVTPOSITOINGNNTKILDTLFIPLSNLPNLTOPASSNTPPPPPAPAPVIOENDRKETVIGLAIGLGVCGLLLILILGLFYKEKTVKKEKYGDVERO

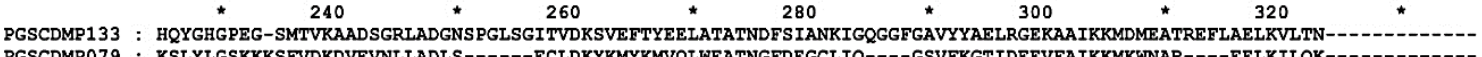

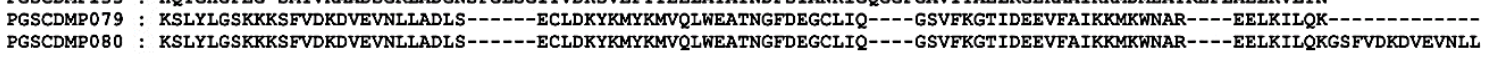

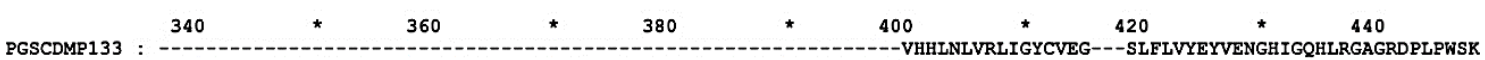

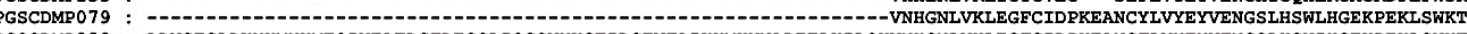
PGSCDMP080 : ADVSECLDKYKMYKMEQIWEATDGFDEGCLIQGSVYKGTIDGEVFAIKKMKWNAREELKILQKVNHGNLVKLEGFCIDPKEANCFLVYEYVENGSLHSWIHGEKPEKLSWKT

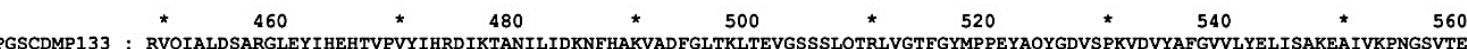
PGSCDMP133 : RVQIALDSARGLEYIHEHTVPVYIHRDIKTANILIDKNFHAKVADFGLTKLTEVGSSSLQTRLVGTFGYMPPEYAQYGDVSPKVDVYAFGVVLYELISAKEAIVKPNGSVTE PGSCDMP079 : RIRIATDVANGLLYIHEHTRPRVVHKDIKSSNILLDSNMRAKVANFGLAKS---GCNAITMHIVGTQGYISPEYLTDGVVSTKMDVFSFGVVLLELVSGKEAIDD-EGKVLW PGSCDMP080 : RLRIATDVANGLLYIHEHTRPRVVHKDIKTSNILIDTNMRAKVANFGLAKS---GCNAITMHIVGTOGYISPEYLTDGIVSTKMDVFSFGVVLLELVSGKEAIDD-EGKVLW

* $\quad 580 \quad * \quad 600 \quad * \quad 620 \quad$ * $\quad 640$

PGSCDMP133 : SKGLVALFEEVLNQPEPDEDLRQLIDPRLGDDYPLDSVRKMAQLAKACTHENPLIRPSMRSIVVALMTLSSSTEDWDVGSFYGNQGMIN PGSCDMP079: AK--ISDFSEGSEERKVRKLQEWMDESLIREELTMESVVNVMTVAISCLNKDPSRRPGMIEIVYALSKSIDLFSDVSEEGPSPRQVTAR PGSCDMP079 : AK--ISDFSEGSEERKVRKLQEWMDESLLREELTMESVVNVMTVAISCLNKDPSRRPGMIEIVYALSKSIDLFSDVSEEGPSPRQVTAR
PGSCDMP080 : AK--ISDFSEGSEERKVKLQEWMDDSLLREELTMESVVNVMSVAISCLNKDPSRRPGMIEIVYALSKSIDLFTDVSEEGLSPRQVTAR

شكل ب. همرديفى كلى سه يروتيين شبهكينازى داراى موتيف ليزين. مستطيلها توالىهاى حفظ شده CxC, را نشان مى CxC قرار دارند. همرديفى با استفاده از در موتيف موسوم به الخوريتم Clustal W صورت گرفت.

Figure 3. General multiple sequence alignment of three LysM-RLKs. Rectangles show the $\mathrm{CxC}$ consensus sequence present in LysM motifs. Multiple Sequence Alignment was performed by using the Clustal $\mathrm{W}$ algorithm.

\section{Discussion}

در جريان حمله بيمارگرهاى گياهى و از آن جمله قارجها، آبشارى از زنها در سلولهاى گياهى فعال مىشوند كه گيرندههاى كينازى و شبه كينازى بخشى از اين زنهاى درگير در پاسخ ايمنى گياهان مىباشند. گيرندهاى شبه كينازى داراى موتيف ليزين در شروع استقرار بيمارگر در گياه ميزبان فعال مىشود. از آنجايى كه تحقيقات متعددى نشان داده بودند كه بيان كيرندههاى شبهكينازى داراى Miya et al. 2007, ) موتيف ليزين در جريان آلودَى با قارجهاى كيتيندار افزايش مىيابند .(Nazarian Firuzabadi and Kushalappa 2019 اگر جه به نظر مىرسد كه اين زنها در جريان حمله بيمارگرها فعال مىشوند، اما ممكن است تنها تعدادى از آنها زن واقعى و تعدادى از آنها نيز به دلايلى زنهاى كاذب بوده و به هر دليلى بيان نشوند (Nazarian Firuzabadi and Kushalappa 2019). كيتين يكى از اجزاى سازنده ديواره برخى از قارج و اووميستها است و نقش اين مولكول به عنوان محرك شناخته شده است (Miya et al. 2007). با توجه به وجود دومين ليزين در ساختار سه زن PGSC0003DMP400061331، PGSC0003DMP400010799 و PGSC0003DMP400010800 به نظر مىرسد كه كيتين و 
اجزاى كوجكتر آن پس از آزادشدن از ديواره يروتيين سلولى قارجها، به واسطه موتيف ليزين موجود در دومين خارج سلولى كيرندهایى شبه كينازى داراى موتيف ليزين شناسايى شود و بتواند ميزان بيان اين زنها را بالا ببرد. بنابر اين بيان اين زنها در نهايت منجر به بيان زنها مسير مب كينازى شده كه در نهايت اين وضعيت به بيان زنهاى مقاومت گياهى مانند بيان گوكانازها، كيتينازها و زنهاى كدكننده يֶ:تيدهاى ضدميكروبى منجر خواهد شد (Bolton et al. 2008). جنين افزايشى در ميزان Wang et al. 2017, Miya et ) بيان زنهاى همولوگ با زن CERK1 آرابيدويسيس قابل انتظار بود al. 2007 اين دومين خارج سلولى در اتصال به كيتين و القا مقاومت به بيماركرها اهميت فراوانى دارد. براى مثال، مطالعه مقاومت نخود به بيمارى نشان داد كه كيتوزان به عنوان يكى از مشتقات شيميايى كيتين، مىتواند نقش مهمى در افـزايش مقاومست گيـاه نخود در برابر بيمارى ايفا كند (Valadi et al. 2013). برخى جدايههاى بيمارگر با استفاده از يروتيينهاى افكتورها سيستم مقاومتى كياه را مهار يا مختل مى كنند و باعث بروز بيمارى مىشوند (Jones and Dangl 2006). يكى از مههمترين مشخصههاى بارز اين يروتيينهاى افكتور وجود موتيف ليزين در توالى يروتيينى آنها مى باشد (Bolton et al. 2008, Mentlak et al. 2011, Marshall et al. 2011) ). اين بروتيينهاى افكتور قادرند مانند لايهاى محافظ اطراف هيف قارج قرار بخيرند و مانع تجزيه شدن آن به وسيله آنزيمهاى هيدروليتيك گياهى شوند. همجنين اين افكتورها مىتوانند با جسبيدن به قطعات كيتين مانع شناسايى كيتين توسط گيرندهاى موجود در سطح گياه شوند (Kombrink and Thomma 2013). كيرندهاى كينازى مورد بررسى در اين مطالعه داراى دو موتيف ليزين بودند كه در توالى دو موتيف يك توالى حفاظت شده يروتيين CXC وجود دارد (Buist et al. 2008, Madsen et al. 2003), كه احتمالاً با تشكيل يلهاى دى سولفيدى به هر دو موتيف كمك مى كند تا به ليعاند مربوطه متصل شوند (Petutschnig et al. 2010). اين مسئله مىتواند يكى از دلايل افزايش بيان اين زنها باشد. به نظر مىرسد كه گيرندههاى كيتين متعدد با هم همكارى مى كنند، با اين حال نحوه همكارى آنها در تأثير بر بيان زنهاى پايين دست جندان مشخص نيست. بنابراين شايد بتوان نتيجه كرفت كه سه زن مورد مطالعه در اين تحقيق با هم در تشخيص كيتين همكارى مى كنند و از اين رو ميزان بيان آنها افزايش يافته است. به عنوان مثال، تغيير در ميزان بيان يروتيين توليدى از اين زنها مىتواند ميزان رياسخ ايمنى را در گياهان تنظيم كند ) Cui et al. 2018, Huang et al. 2020). از آنجايى كه هر سه يروتيين از لحاظ تعداد اسيدآمينه و موتيف به يكديكر شباهت بالايى دارند، ممكن است اختلاف بيان آنها مربوط به تعداد و ساختار دومينهاى تشكيل دهنده باشد. يكى از اختلافات كه بين دومينهاى يروتيينهاى حاصل از دو زن PGSC0003DMP400010799، 
PGSC0003DMP400010800 و زن PGSC0003DMP400061331 وجود دارد، جايكزينى اسيدآمينه يروتيين تيروزين با اسيدآمينه فنيل آلانين در جايگاه فعال آنزيمهاست كه به دليل كاركرد يكسان اين دو اسيدآمينه به نظر نمىرسد كه اين موضوع بر عملكرد موتيف ليزين مؤثر باشد (شكل (YB ايمنى ذاتى گياهان حاصل شده است. در حال حاضر، اجزاى گِائين دست كيرندهاى شبه كينازى داراى موتيف ليزين جندان مشخص نيستند و به نظر مىرسد كه بايد منتظر ماند تا تحقيقات بيشتر بتوانند نقش اجزاء ديگر اين پازل را مشخص كنند (Gong et al. 2020).

\section{Conclusion}

كَياهان در طى دوره رشد با تنشهاى مختلفى مواجه مىشوند. سازوكارهاى مختلفى جهت سازش بـا تنشهاى زيستى و غيرزيستى در سطح سلولى و مولكولى در آنها تكامل يافته است و به علت وجـود اين سازوكارها دريافت سيخنال خارجى، ياسخ مناسبى بـه شـرايط محيطـى نشـان مسىدهنـد. القـاى مقاومت نسبت به بيماركر از راهكارهايى است كه گياهان براى مقابله با تنشهاى زيستى به كـار مسى برند و با توجه به اين كه امروزه از سموم شيميايى مضر براى مبارزه در برابر بيمارگرها و عوامل تنشزا استفاده مىشود، شايد القا مقاومت از طريق تيمار زياهان با محركها به عنـوان يـك فنـاورى جديـــ جهت كنترل بيمارىهاى گياهى يك راهكار مناسب در اين زمينه باشد.

\section{References}

1. Abedini A, Amiri H, Karimi K (2020) Efficient biobutanol production from potato peel wastes by separate and simultaneous inhibitors removal and pretreatment. Renewable Energy 160:269-77.

2. Arrighi J F, Barre A, Amor BB, Bersoult A, Soriano LC, Mirabella R, de CarvalhoNiebel F, Journet E-P, Ghérardi M, Huguet T (2006) The Medicago truncatula lysine motif-receptor-like kinase gene family includes NFP and new nodule-expressed genes. Plant Physiology 142:265-279.

3. Asai T, Tena G, Plotnikova J, Willmann MR, Chiu WL, Gomez-Gomez L, Boller T, Ausubel F M, Sheen J (2002) MAP kinase signalling cascade in Arabidopsis innate immunity. Nature 415:977-983.

4. Bateman A, Bycroft M (2000) The structure of a LysM domain from E. coli membrane-bound lytic murein transglycosylase D (MltD). Journal of Molecular Biology 299:1113-1119.

5. Bittel P and Robatzek S (2007) Microbe-associated molecular patterns (MAMPs) probe plant immunity. Current Opinion in Plant Biology 10:335-341. 
6. Bolton MD, Van Esse HP, Vossen JH, De Jonge R, Stergiopoulos I, Stulemeijer IJ, Van Den Berg GC, Borrás-Hidalgo O, Dekker HL, De Koster CG (2008) The novel Cladosporium fulvum lysin motif effector Ecp6 is a virulence factor with orthologues in other fungal species. Molecular Microbiology 69:119-136.

7. Buist G, Steen A, Kok J, Kuipers OP (2008) LysM, a widely distributed protein motif for binding to (peptido) glycans. Molecular Microbiology 68:838-847.

8. Chisholm ST, Coaker G, Day B, Staskawicz BJ (2006) Host-microbe interactions: shaping the evolution of the plant immune response. Cell 124:803-814.

9. Couto D, Zipfel C (2016) Regulation of pattern recognition receptor signalling in plants. Nature Reviews Immunology 16:537.

10. Cui Y, Li X, Yu M, Li, R, Fan, L, Zhu, Y, Lin, J (2018) Sterols regulate endocytic pathways during flg22-induced defense responses in Arabidopsis. Development 145.

11. Durrant WE, Dong X (2004) Systemic acquired resistance. Annual Review of Phytopathology 42:185-209.

12. Faostat (2016) Food and agriculture organization of the united nations, 2010. Roma, Italy.

13. Ghawana S, Paul A, Kumar H, Kumar A, Singh H, Bhardwaj P K, Rani A, Singh R S, Raizada J, Singh K (2011) An RNA isolation system for plant tissues rich in secondary metabolites. BMC Research Notes 4:1-5.

14. Gong BQ, Wang FZ, Li JF (2020) Hide-and-seek: chitin-triggered plant immunity and fungal counterstrategies. Trends in Plant Science (In press).

15. Huang C, Yan Y, Zhao H, Ye Y, Cao Y (2020) Arabidopsis CPK5 Phosphorylates the Chitin Receptor LYK5 to Regulate Plant Innate Immunity. Frontiers in Plant Science 11:702.

16. Jonak C, Ökrész L, Bögre L, Hirt H (2002) Complexity, cross talk and integration of plant MAP kinase signalling. Current Opinion in Plant Biology 5:415424.

17. Jones JD, Dangl JL (2006) The plant immune system. Nature 444:323-329.

18. Kaku H, Nishizawa Y, Ishii-Minami N, Akimoto-Tomiyama C, Dohmae N, Takio K, Minami E, Shibuya N (2006) Plant cells recognize chitin fragments for defense signaling through a plasma membrane receptor. Proceedings of the National Academy of Sciences 103:11086-11091.

19. Kombrink A, Thomma BP (2013) LysM effectors: secreted proteins supporting fungal life. PLoS Pathogens 9:e1003769.

20. Limpens E, Franken C, Smit P, Willemse J, Bisseling T, Geurts R (2003) LysM domain receptor kinases regulating rhizobial Nod factor-induced infection. Science 302:630-633.

21. Livak KJ, Schmittgen TD (2001) Analysis of relative gene expression data using real-time quantitative PCR and the $2^{-\Delta \Delta C T}$ method. Methods 25:402-408. 
22. Madsen EB, Madsen LH, Radutoiu S, Olbryt M, Rakwalska M, Szczyglowski K, Sato S, Kaneko T, Tabata S, Sandal N (2003) A receptor kinase gene of the LysM type is involved in legumeperception of rhizobial signals. Nature 425:637-640.

23. Marshall R, Kombrink A, Motteram J, Loza-Reyes E, Lucas J, HammondKosack KE, Thomma BP, Rudd JJ (2011) Analysis of two in planta expressed LysM effector homologs from the fungus Mycosphaerella graminicola reveals novel functional properties and varying contributions to virulence on wheat. Plant Physiology 156:756-769.

24. Mentlak TA, Talbot NJ, Kroj T (2011) Effector translocation and delivery by the rice blast fungus Magnaporthe oryzae. Effectors in Plant-Microbe Interactions 219241.

25. Miya A, Albert P, Shinya T, Desaki Y, Ichimura K, Shirasu K, Narusaka Y, Kawakami N, Kaku H, Shibuya N (2007) CERK1, a LysM receptor kinase, is essential for chitin elicitor signaling in Arabidopsis. Proceedings of the National Academy of Sciences 104:19613-19618.

26. Moslemkhani C, Mozafari J (2016) Management of Bacterial Wilt Disease of Potato by Health Assay of Seed Tubers. Plant Pathology Science 5:62-75. (In Persian with English Abstract).

27. Nakagami H, Pitzschke A, Hirt H (2005) Emerging MAP kinase pathways in plant stress signalling. Trends in Plant Science 10:339-346.

28. Nazarian Firuzabadi F, Kushalappa A (2019) Polymorphism and Expression Analysis of two Potato Receptor Genes (LysM-RLKs), Following Alternaria solani Infection. Applied Researches in Plant Protection 8:33-48. (In Persian with English Abstract).

29. Petutschnig EK, Jones AM, Serazetdinova L, Lipka U, Lipka V (2010) The lysin motif receptor-like kinase (LysM-RLK) CERK1 is a major chitin-binding protein in Arabidopsis thaliana and subject to chitin-induced phosphorylation. Journal of Biological Chemistry 285:28902-28911.

30. Radutoiu S, Madsen LH, Madsen EB, Felle HH, Umehara Y, Grønlund M, Sato S, Nakamura Y, Tabata S, Sandal N (2003) Plant recognition of symbiotic bacteria requires two LysM receptor-like kinases. Nature 425:585-592.

31. Rezzonico F, Rupp O, Fahrentrapp J (2017) Pathogen recognition in compatible plant-microbe interactions. Scientific Reports 7:1-12.

32. Rich AE (2013) Potato Diseases. Academic Press.

33. Shiu SH, Bleecker AB (2001) Plant receptor-like kinase gene family: diversity, function, and signaling. Science's STKE 200:re22-re22.

34. Takahashi Y, Soyano T, Kosetsu K, Sasabe M, Machida Y (2010) HINKEL kinesin, ANP MAPKKKs and MKK6/ANQ MAPKK, which phosphorylates and activates MPK4 MAPK, constitute a pathway that is required for cytokinesis in Arabidopsis thaliana. Plant and Cell Physiology 51:1766-1776.

35. Thomma BP, Nürnberger T, Joosten MH (2011) Of PAMPs and effectors: the blurred PTI-ETI dichotomy. The Plant Cell 23:4-15. 
36. Valadi S, Soleimani M J, Karamian G K, Ghiasvand T (2013) Effect of salicylic acid \& chitosan on induction of resistance in chickpea against fusarial wilt and root rot. Iranian Journal of Plant Pathology 2:181-199. (In Persian with English Abstract).

37. Wang C, Wang G, Zhang C, Zhu P, Dai H, Yu N, He Z, Xu L, Wang E (2017) OsCERK1-mediated chitin perception and immune signaling requires receptor-like cytoplasmic kinase 185 to activate an MAPK cascade in rice. Molecular Plant 10:619-633.

38. Zhang XC, Wu X, Findley S, Wan J, Libault M, Nguyen HT, Cannon S B, Stacey G (2007) Molecular evolution of lysin motif-type receptor-like kinases in plants. Plant Physiology 144:623-636.

39. Zipfel C (2009) Early molecular events in PAMP-triggered immunity. Current opinion in Plant Biology 12:414-420. 